UDC $622.24+621.694 .2$

Ye. I. Kryzhanivskyi, Academ. of NAS of Ukraine,
Dr. Sc. (Tech.), Prof.,
orcid.org/0000-0001-6315-1277,
D. O. Panevnyk,
orcid.org/0000-0002-7853-5051
DOI: $10.29202 /$ nvngu/2019-1/7

State Higher Educational Institution "Ivano-Frankivsk National Technical University of Oil and Gas”, Ivano-Frankivsk, Ukraine, e-mail: rector@nung.edu.ua; den.panevnik@gmail.com

\title{
THE STUDY ON THE FLOWS KINEMATICS IN THE JET PUMP'S MIXING CHAMBER
}

Purpose. To improve the simulation method of kinematic parameters distribution for mixed flows in a flowing part of a downhole jet pump.

Methodology. There is developed an analytical model for distribution of flow kinematic parameters in the mixing chamber of a downhole jet pump as potential flows and the turbulent layer between them with an uneven velocity profile, which is approximated using basic functions. Integrated analysis techniques for interaction of asymmetric flooded turbulent jets are applied during simulation.

Findings. There is analyzed a structure of the flow at the mixing chamber inlet of the jet pump by applying the theory of a flooded jet of fluid that moves in the accompanying flow. A possibility of simulating the process of the jet pump mixing is presented. There is also shown a possibility of simulating the mixing process of coaxial flows as selfsimilar velocities profiles of potential and shear flows of the variable section with a three-layer structure. There is accepted a uniform velocity profile for the areas of potential flows while a non-linear profile is accepted for the shear flow, placed between them. These profiles retain an approximate self-similarity during the entire initial area of a submerged jet. Integration of the accepted velocity profile with regard to the conditions of the transition between potential and shear flows allows determining the uneven distribution of kinematic parameters for mixed flows in a flowing part of a downhole jet pump.

Originality. The novelty of this research article is to establish the relationship between self-similar velocities profiles of potential and shear flows of the variable structure, boundaries of the mixed flows and mutual orientation of elements in a flowing part of the jet pump.

Practical value. The presented method for estimating the unevenness of the velocity profile in the mixing chamber of the jet pump allows taking into account the design and operational characteristics of the well bore ejection system when designing the distribution of kinematic parameters of the mixed streams. The established relationship between uneven distribution of velocities and the ratio of flows to mixed streams, geometric sizes and mutual orientation of elements can be used for designing structures and predicting the operating conditions of the well borehole pump.

Keywords: fluid-velocity, jet pump, mixing of flows profile, oil well

Introduction. The use of non-traditional technologies allows intensifying the processes of construction and operation of oil and gas wells. The absence of moving parts, uncomplicated design and low cost of production have led to the prevalence of the use of well jet pumps in the implementation of individual technological operations for the development of hydrocarbon deposits. The key advantage of using downhole jet pumps is the ability to preserve the permeability of the productive horizon during its initial opening [1], to increase the service life of aging gas fields [2], the ability to dispose low-pressure oil gas, burned in flare systems, [3] and to produce heavy oil [4]. Weatherford International Ltd, a leader in the use of ejection technology, is ranked $5^{\text {th }}$ in the global ranking of oilfield service companies and is successful due to the production and use of downhole jet pumps. The ejection technology is used by such world leaders in the market of oilfield services as Schlumberger, Baker Hughes, Royal Dutch Shell, Chevron, Conoco Philips and a number of other national and regional companies.

Despite the wide range of applications, the efficiency of using downhole jet pumps does not always meet the

(C) Kryzhanivskyi Ye.I., Panevnyk D. O., 2019 requirements, hindering the spread of ejection technologies significantly. This is primarily due to insufficient study of the theoretical issues of the use of jet pumps in the implementation of production processes for the development of oil and gas fields. The overwhelming majority of methods for calculating ejection systems provides an approximate solution of the problem on the basis of previously accepted averaged values of the hydrodynamic parameters of the mixed flows. The development of the theoretical basis for the use of well jet pumps allows increasing the efficiency of the implementation of ejection technologies and is an urgent task.

Analysis of the recent research. The nature of velocity distribution of the mixed flows in the flow part of the jet pump predetermines the choice of the necessary design parameters $[5,6]$ in designing and operating downhole ejection systems. The shape of the profile of kinematic parameters is characterized by the magnitude of the non-uniformity coefficient of the distribution of mixed flow velocities, which is determined mainly by an experiment. The direct method for determining the nonuniformity coefficient of velocity profile provides for an experimental study of the flow kinematics in the flow part of hydraulic elements equivalent to the mixing chamber of a jet pump. In the process of indirect deter- 
mining of the non-uniformity coefficient, there is applied an experimental velocity profile obtained using the Pitot-Prandtl method.

Theoretical models of velocity distribution in the submerged jet, which is distributed in the accompanying flow, are first obtained by H. Schlichting and provide a linear profile of hydrodynamic parameters in the boundary layer of an incompressible fluid. Modern analytical models of velocity distribution in the mixing chamber of a jet pump involve the use of a system of differential equations of motion for a viscous fluid [7]. The application of numerical modeling and particular computer programs [8] allows us to simplify the solution to the problem of finding the theoretical distribution of velocities in the mixing chamber of a jet pump.

Unsolved aspects of the problem. Analytical models of the operating process of a well ejection system take into account the coefficient of non-uniformity of the velocity distribution of axisymmetric flows related to the inlet section of the mixing chamber of the jet pump. In the process of direct determination of the non-uniformity coefficient, the averaged distribution of kinematic parameters in the mixing chamber of the jet pump is taken into account. The averaged values of the non-uniformity coefficient differ significantly from similar parameters related to a fixed cross-section of the mixing chamber, as a result of which the direct method for studying kinematic parameters does not provide the necessary accuracy for determining the operating mode of the borehole ejection system. During the indirect determination of the nonuniformity coefficient, the values of the instantaneous velocities of the mixed flows are determined using a full head tube, the value of which is comparable to the size of the flow part of the ejection system. Constrained conditions of using the ejection system in the well is the reason for the significant error in the construction of the experimental velocity profile in the mixing chamber of the jet pump using the Pitot-Prandtl method. Obtained in the process of experimental studies, the value of the coefficient of non-uniformity is a constant value and does not take into account the change in the design and operating parameters of the well jet pump.

The theoretical distribution of velocities in the submerged flow obtained by Schlichting for the main part of the turbulent jet does not take into account the existence of potential areas of the working and injected flows in the inlet section of the mixing chamber of the jet pump. The solution of the system of differential equations of mixed flows is a difficult task even for incompressible liquids and requires the use of special decoupling methods (for example, Bessel functions) and is carried out, as a rule, by the approximate method neglecting the value of individual constituent elements.

Due to the imperfections of empirical and theoretical models of velocity distribution in the mixing chamber of a jet pump, the error in predicting the pressure of the borehole ejection system can be $80 \%$.

The objective of the article. The purpose of the work is to improve the simulation method of kinematic parameters distribution for mixed flows in a flowing part of a downhole jet pump.
Presentation of the main research. In the process of conducting research, it is necessary to establish the interconnection between the coefficient of uneven distribution of velocities and the basic quantities characterizing the geometric and kinematic parameters of the jet pump.

$$
\varphi_{2}=f\left(K_{p}, \bar{l}_{n}, i\right)
$$

where $K_{p}$ is the main geometric parameter of the jet pump; $l_{n}$ is a relative distance between the working nozzle and the mixing chamber; $i$ is an injection rate of the jet pump.

The magnitude of the non-uniformity coefficient does not depend on viscosity if the Reynolds number of the mixed flow is $\operatorname{Re} \geq 10^{6}$ and the jet pump is operated in a self-similar mode.

We will determine the structure of the flow at the inlet to the mixing chamber using the theory of a submerged jet of liquid moving in the accompanying flow.

In the initial section of the jet (Fig. 1) at the outlet of the working nozzle of the jet pump, the value of the flow velocity is constant over the entire section. The equality of the workflow velocities $V_{n}=$ const is maintained in the central part of the jet, forming the core of the jet with a constant velocity or the area of the potential flow. The potential core in the direction of the flow decreases in volume, and there is formed a region of inhibited liquid in the peripheral part, which is called the boundary layer of the jet. A potential core region, thus, has the shape of a cone with a vertex, which determines the final section of the initial section and the initial section of the main section.

The straight lines " $n$ " in Fig. 1 separate a potential core region from the boundary layer of the jet. The concomitant or injected flow at the inlet to the mixing chamber also consists of two regions. In the peripheral part of the injected flow there is a potential region with a constant velocity of the fluid $V_{i}=$ const. In the direction of the jet pump axis, the region of the injected potential flow is bordered by the boundary layer of the jet.

The lines " $m$ " in Fig. 1 are the boundaries of the contact of an external potential injected flow with the boundary layer of the jet. The dotted lines " $k$ " determine the diameter of the working jet in its initial cross section, that is, at the outlet of the working nozzle of the jet pump. In the main section in the direction of flow, the volume of the potential region of the injected flow continues to decrease. The lines " $m$ " having been connected with the walls of the mixing chamber, the mixed flow consists exclusively of the boundary layer.

Given that the coefficient of non-uniformity of the flow rate is determined by the ratio of its average and maximum velocities, we can write the general formula of equations, the solution of which allows solving the research problem

$$
\varphi_{2}=\frac{V_{m}}{V_{\max }}=\frac{\int_{S} V(r) d S / S}{V_{\max }},
$$

where $V_{m}$ is average velocity of the mixed flow; $V_{\max }$ is the maximum velocity of the mixed flow; $V(r)$ is theo- 


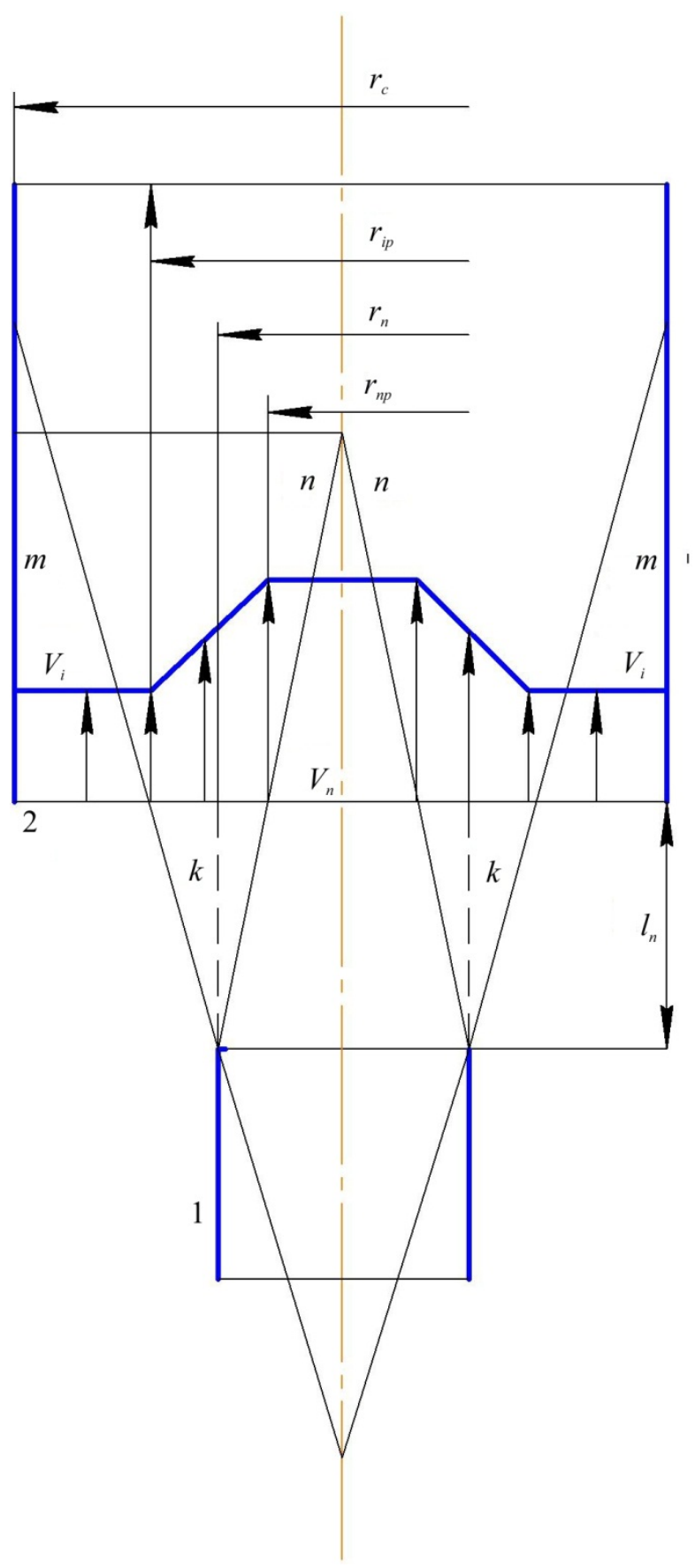

Fig. 1. The motion of the submerged jet in the flow part of the jet pump:

1 - a working nozzle; 2 - a mixing chamber

retical (adopted) velocity distribution profile; $S$ is the cross-sectional area of the mixed flow at the inlet to the mixing chamber.

The task of determining the non-uniformity rate, thus, is reduced to the integration of the adopted velocity profile in the inlet section of the mixing chamber of the jet pump.

By studying the mixing process of coaxial turbulent jets, it was found that the velocity profile in the boundary layer can be approximated as elementary functions that preserve an approximate auto-model throughout the entire length of the initial segment. We take the flow velocity profile in the boundary layer of the jet in the form of an algebraic function

$$
V=f\left(1-\eta^{2}\right),
$$

where $\eta$ is a dimensionless radius of the jet.

The correctness of the choice of the function type can be checked at the stage of experimental verification of the results obtained. In addition, the type of the adopted function should provide the necessary dimensionality of the obtained coefficient of non-uniformity, namely, to be a dimensionless quantity, as well as the equation of the characteristics of the jet pump, which should include it. The adopted function should also provide conditions for the transition at the boundaries of individual profile regions.

In order to simplify the form of the equations for determining the non-uniformity rate when modeling the velocity profile, it is assumed that there is no influence of the mixing chamber wall on the flow velocity. According to the accepted assumption, the velocity of the fluid on the wall of the mixing chamber has a positive value in contrast to zero in real flows.

The accepted assumption increases the region of the velocity profile and the average flow velocity, that is, it gives overestimated values of the non-uniformity coefficient. Such a scheme for formulating a research problem is generally accepted [9] when modeling the relationship between the hydrodynamic and kinematic parameters of a jet pump.

According to Fig. 2 we take a model of fluid motion in the inlet section of the mixing chamber in the form of two potential flow areas with a significant difference in velocity separated by a layer with a sliding flow, the

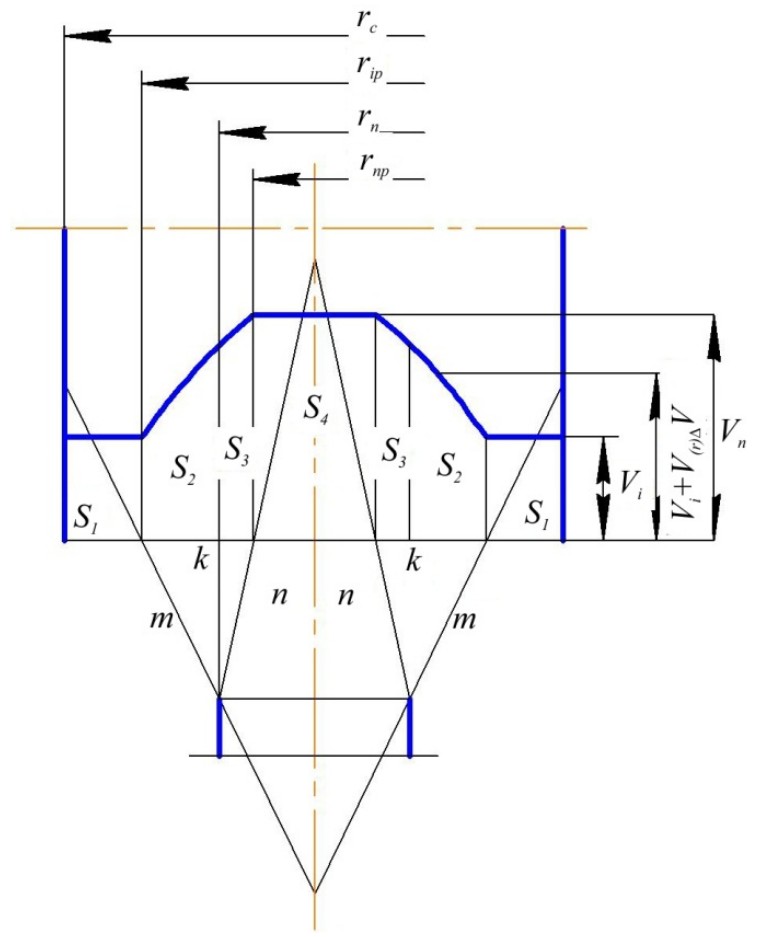

Fig. 2. Flow velocity profile at the inlet to the mixing chamber of the jet pump 
thickness of which increases in the direction of the jet pump diffuser.

The limit of separation of injected and workflow has a radius $r_{n}$ (Fig. 2). The velocity profile for the threelayer structure of the flow according to the accepted model is (Fig. 2):

$$
\begin{gathered}
S_{1}: \quad r_{i p} \leq r \leq r_{c} ; \quad V=V_{i} . \\
S_{2}: \quad r_{n} \leq r \leq r_{i p} ; \quad V=V_{i}+V(r) \Delta V ; \\
V(r)=f(\eta)=\left(1-\eta^{2}\right) ; \\
\Delta V=V_{n}-V_{i} ; \quad \eta=\frac{r-r_{n p}}{r_{i p}-r_{n p}} . \\
S_{3}: \quad r_{n p} \leq r \leq r_{n} ; \quad V=V_{i}+V(r) \Delta V ; \\
V(r)=f(\eta)=\left(1-\eta^{2}\right) ; \\
\Delta V=V_{n}-V_{i} ; \quad \eta=\frac{r-r_{n p}}{r_{i p}-r_{n p}} . \\
S_{4}: \quad 0 \leq r \leq r_{p} ; \quad V=V_{i}+\Delta V ; \\
\Delta V=V_{n}-V_{i} .
\end{gathered}
$$

Let us characterize the velocity profile in the areas $S_{1}, S_{2}, S_{3}, S_{4}$ using equations (4-7). The area $S_{1}$ is bounded by the inner surface of the mixing chamber and the cylindrical surface, which determines the inner boundary of the potential area of the injected flow. In the area $S_{1}$, the velocity of the injected flow is kept constant, that is, the velocity profile is uniform $V_{i}=$ const. The area $S_{2}$ is located between the potential zone of the injection flow and the cylindrical surface, the radius of which is equal to the radius of the working nozzle of the jet pump. The velocity profile in this area is determined by the algebraic function (5) according to the accepted model. Let us determine the correspondence of the velocity profiles of the area $S_{1}$ and the area $S_{2}$ to their limit determined by the radius $r_{i p}$. Considering formulas (5), the flow rate at a distance $r_{i p}$ from the axis of the mixing chamber is

$$
V=V_{i}+V(r) \Delta V=V_{i}+\left[1-\left(\frac{r-r_{n p}}{r_{i p}-r_{n p}}\right)^{2}\right]\left(V_{n}-V_{i}\right) .
$$

In the case of $r=r_{i p}$ we receive $V=V_{i}$, that is, the conditions of transition are provided. The velocity profile according to formula (5) also takes place in the area $S_{3}$ limited by the radius of the working nozzle and the radius of the potential core of the working stream. Given that in the areas $S_{2}, S_{3}$ the velocity profiles are determined by a single function, there is no need to check the transition conditions at the point of their contact. The area $S_{4}$ is a potential core of the workflow with a uniform velocity profile $V_{n}=$ const. Let us determine the value of the velocity at the boundary of the contact areas $S_{3}, S_{4}$ (radius $r_{n p}$ ), taking into account the distribution adopted in the area $S_{3}$. If $r=r_{n p}$, then $\eta=\frac{r-r_{n p}}{r_{i p}-r_{n p}}=0$, then ac- cording to (8) $V=V_{n}$, that is, conditions for the transition of velocity profiles on the border of the areas $S_{3}, S_{4}$ are provided.

Then the values of the quantities from formula (2) for each of the areas are determined successively. Using the ratio

$$
Q=\int_{S} V d s
$$

we determine the flow rate in certain parts of the mixing chamber.

In particular, for the area $S_{1}$, moving to the cylindrical coordinates $d s=2 \pi r d r$ we get (Fig. 2)

$$
Q_{1}=\int_{r_{i p}}^{r_{c}} 2 V_{i} \pi r d r=\left.2 V_{i} \pi \frac{r^{2}}{2}\right|_{r_{i p}} ^{r_{c}}=\pi\left(r_{c}^{2}-r_{i p}^{2}\right) V_{i} .
$$

Having added the equations that determine the flow rate in areas 1, 2, 3, 4 we obtain

$$
\begin{aligned}
Q_{1234}= & \frac{r_{c}^{2}-r_{n}^{2}\left(0.0292 \bar{l}_{n}^{2}+0.3008 \bar{l}_{n}+1\right)}{r_{c}^{2}-r_{n}^{2}} Q_{i}+ \\
& +\left(0.0296 \bar{l}_{n}^{2}+0.2866 \bar{l}_{n}+1\right) Q_{n} .
\end{aligned}
$$

The average flow velocity $V_{m}$ is determined by the division of the equation (11) into the area of the mixing chamber $f_{m}=\pi r_{c}^{2}$. Then, given that $\frac{r_{n}^{2}}{r_{c}^{2}}=K_{p}^{-1}$ we get

$$
\begin{gathered}
V_{m}=\left(0.0296 \bar{l}_{n}^{2}+0.2866 \bar{l}_{n}+1\right) \frac{Q_{n}}{\pi r_{c}^{2}}+ \\
+\frac{1-K_{p}^{-1}\left(0.0292 \bar{l}_{n}^{2}+0.3008 \bar{l}_{n}+1\right)}{\pi\left(r_{c}^{2}-r_{n}^{2}\right)} Q_{i} .
\end{gathered}
$$

The maximum flow rate takes place on the axis of the mixing chamber

$$
V_{\max }=\frac{Q_{n}}{\pi r_{n}^{2}} .
$$

Then, in accordance with formula (2), we obtain the equation for determining the non-uniformity coefficient of the velocity distribution in the jet pump mixing chamber

$$
\begin{gathered}
\varphi_{2}=\frac{0.0296 \bar{l}_{n}^{2}+0.2866 \bar{l}_{n}+1}{K_{p}}+ \\
+\frac{1-K_{p}^{-1}\left(0.0292 \bar{l}_{n}^{2}+0.3008 \bar{l}_{n}+1\right)}{K_{p}-1} i .
\end{gathered}
$$

The dependence obtained allows taking into account the design of the flow part and the mode of operation of the jet pump in the process of analytic determination of its pressure. In addition to improving the quantitative indicators, the obtained equation should correspond to the physical meaning of the velocity distribution process in the mixing chamber. In particular, an increase in the diameter of the mixing chamber should increase the 
non-uniformity of the velocity profile, that is, reduce the value of the non-uniformity coefficient. The growth of the injection coefficient or the rate of the injected flow, on the contrary, should cause leveling of the velocity profile and an increase in the magnitude of the nonuniformity coefficient.

Considering the design features of the ejection systems used in the oil and gas industry, the following geometric relationships of jet pumps $K_{p}$ were considered for analysis: $2.041 ; 3.16 ; 3.95 ; 4.938 ; 6.25$. The values of the geometric parameter provide all sizes of low-pressure and high-pressure jet pumps used in the development, operation and drilling of wells.

In the process of analyzing the characteristics of the above jet pump designs, the injection coefficient varied in the range from $i=0$ to $i=3.4$, and the distance between the working nozzle and the mixing chamber from $\bar{l}_{n}=0$ to $\bar{l}_{n}=6.0$.

In quantitative terms, the value of the non-uniformity coefficient should not exceed the limit value for real flows. For the personified coefficients, this magnitude is $\varphi=0.975$, and its value for short cylindrical channels has been confirmed by numerous experiments and is beyond doubt. The value accepted by Sokolov E. Ya., obviously, is the maximum allowable and the value of the injection coefficient should not be greater than it. We define the possibility of achieving a generalized non-uniformity coefficient of values $\varphi_{2}=1$. Using the obvious relations we can write

$$
\varphi_{2}=\frac{V_{m}}{V_{\max }}=\frac{Q_{c}}{f_{c}}: \frac{Q_{n}}{f_{n}}=\frac{Q_{n}(1+i)}{\pi r_{c}^{2}}: \frac{Q_{n}}{\pi r_{n}^{2}}=(1+i) \frac{r_{n}^{2}}{r_{c}^{2}}=\frac{1+i}{K_{p}} .
$$

Having performed the substitution $\varphi_{2}=1$ we get $i=$ $=K_{p}-1$. The calculation of the limits of injection coefficient values shows that the relation $i_{\max }<K_{p}-1$ is always satisfied. Thus, the value $\varphi_{2}=1$ cannot be achieved in real structures and the value of the generalized nonuniformity coefficient should be less than $\varphi_{2}=1$.

In order to analyze the equation describing the nonuniformity coefficient of the velocity profile, we make (Fig. 3) the dependences of the non-uniformity coefficient on values of the injection coefficient for different ratios $K_{p}$ of the jet pump.

The dependence $\varphi_{2}=f(i)$ is constructed by equation (14) and has a linear character. An increase in the value of the injection coefficient leads to equalization of the velocity profile and an increase in the values of the nonuniformity coefficient.

The value of a geometric parameter has an inverse effect on the value of the non-uniformity coefficient: the larger the value $K_{p}$ is, the smaller the value of the coefficient $\varphi_{2}$ is, that is, the velocity profile is more uniform. The horizontal dotted line in the graph of Fig. 3 determines the maximum permissible values of the non-uniformity coefficient.

In order to study the distribution of the kinematic parameters of hydraulic flows in the flow part of the jet pump, simulation modeling was carried out using the SolidWorks software package. To do this, a three-dimensional model of a jet pump was created in this soft-

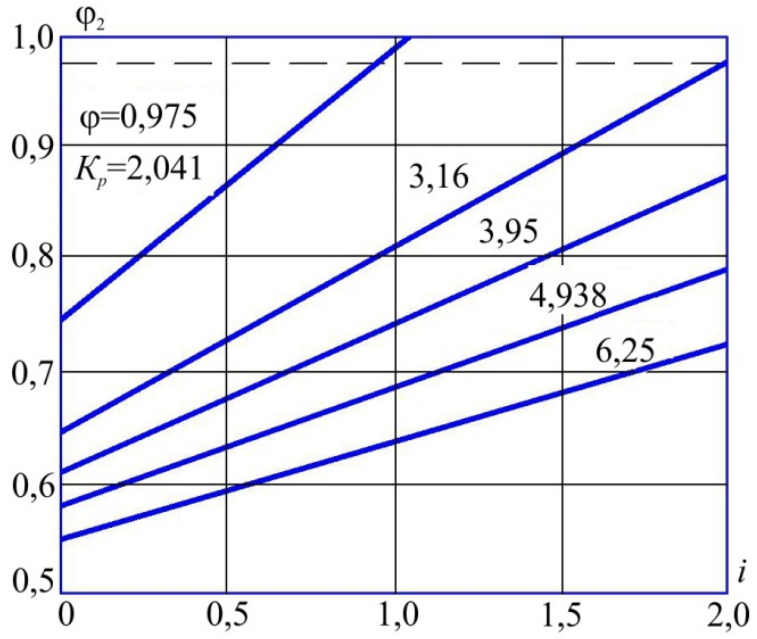

Fig. 3. Dependence of the non-uniformity coefficient of the velocity distribution in the mixing chamber of the jet pump on the value of the injection coefficient and the main geometric parameter

ware package (Fig. 4) and a block of the SolidWorks FlowSimulation program was chosen, which made it possible to build velocity profiles of the mixed flows.

The boundary conditions were adopted as the values of the flow rate of the working and injected flows and the pressure in the characteristic sections of the jet pump.

To create the internal flow area and determine the calculation area of the flow part of the jet pump, there are used restrictive planes. In the process of splitting the jet pump model into design elements, the finite element mesh in the inlet area to the mixing chamber is made denser. The uneven finite element mesh made it possible to increase the accuracy of the velocity profile construction with a slight increase in the duration of the computational operations.

As a result of the simulation, there were derived velocity profiles in the ascending section of the mixing chamber for different ratios of the injection coefficient $i$ and the main geometric parameter $K_{p}$ of the jet pump (Fig. 5).

The results obtained using computer simulation confirm the analytical dependence proposed by the authors for determining the non-uniformity of the velocity distribution in the mixing chamber of the jet pump.

The results obtained are consistent with CFD modeling of the velocity profile transformation in the flow

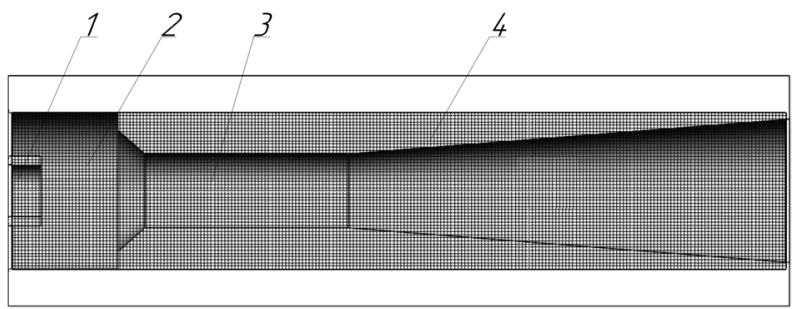

Fig. 4. Computational model of the flow part of the jet pump:

$1-a$ working nozzle; $2-$ a receiving chamber; $3-a$ mixing chamber; 4 - a diffuser 

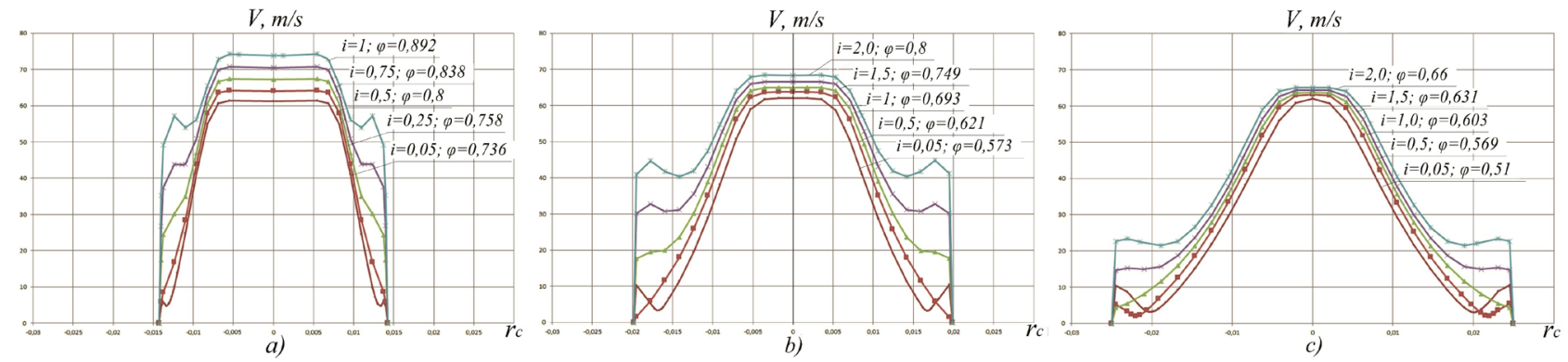

Fig. 5. Velocity profiles in the inlet section of the mixing chamber for different ratios of the injection coefficient $i$ and the main geometric parameter $K_{p}$ of the jet pump:

$a-K_{p}=2.041 ; b-K_{p}=3.95 ; c-K_{p}=6.25$

part of the jet pump using turbulence models. On the basis of the ANSYS Workbench platform, there was obtained a reduction in the uneven distribution of velocity [10] with an increase in the distance between the working nozzle and the mixing chamber of the jet pump.

Conclusions and recommendations for further research.

1. There is developed a three-layer mathematical model of mixing flows in the form of coaxial potential flows with a uniform velocity distribution and a landslide flow of variable structure with an algebraic velocity profile located between them.

2. The relationship between the hydrodynamic flow parameters and the non-uniform distribution of velocities in the mixing chamber of the jet pump has been established.

3. There is determined a certain influence of the design and operating parameters of the downhole ejection system on the nature of the velocity distribution in the mixing chamber of the jet pump.

The prospect for further development of the direction involves studying the process of transformation of the mixed flows structure when changing the relative orientation of the elements of the flow-through part of the ejection system and the mechanism of kinematic parameters distribution in case of significant (supercritical) distances between the working nozzle and the mixing chamber of the well jet pump.

\section{References.}

1. Yong, H., Lihong, Z., Deyong, Z., Hualin, L., Jinying, W., Jinshen, Y., Yugang, Z. and Zhibin, W., 2016. Study on structure parameters of reverse circulation drill bit secondary injector device based on injector coefficient. In: Proc. IADC/SPE Asia Pacific Drilling Technology Conference, Singapore. August 22-24. DOI: $10.2118 / 180539-M S$.

2. Syed, M. P., Najam, B. and Sacha, S., 2014. Surface jet pumps enhance production and processing. Journal of Petroleum Technology, 66(11), pp. 134-136.

3. Leagas, T., Seefeldt, G. and Hoon, D., 2016. Ejector Technology for efficient and cost effective flare gas recovery. In: Proc. GPA-GCC $24^{\text {th }}$ Annual Technical Conference, Kuwait City [online], May 10-11, 10 p. Available at: <https://www.zeeco.com/.../GPA-Kuwait-Final-Paper-2016.pd.> [Accessed 24 November 2017].
4. Mohammed, S. K., 2016. The experience of using jet pumps with hydraulic pumping bottom-hole assemblies to reactivate Idle Wells in a heavy oil reservoir in the East Soldado field. In: Proc. SPE Trinidad and Tobago Section Energy Resources Conference, Port of Spain. June 13-15 [online]. Available at: <https://www.onepetro. org/conference-paper/SPE-180799-MS > https://www. zeeco.com/.../GPA-Kuwait-Final-Paper-2016.pd.> [Accessed 8 October 2017].

5. Zhao, S. and Sakuragi, S., 2018. Performance improvement of underwater jet pump by optimal arrangement of primary jet stream. Journal of Fluid Science and Technology, 13(1), 11 p. DOI: 10.1299/jfst.2018jfst0004. 6. Panevnyk, D. O. and Velichkovich, A. S., 2017. Assessment of the stressed state of the casing of the abovebit hydro-elevator. Neftyanoe Khozyaistvo, 1, pp. 70-73.

7. Yao, D., Lee, K., Ha, M., Cheong, C. and Lee, I., 2018. Development of Hybrid Airlift-Jet Pump with its Performance Analysis. Applied Science, 8, pp. 1-18.

8. Sheha, A.A.A., Nasr, M., Hosien, M.A. and Wahba, E. M., 2018. Computational and experimental study on the water-jet pump performance. Journal of Applied Fluid Mechanics, 11(4), pp. 1013-1020.

9. Zhu, H.-Y., Liu, Q.-Y. and Wang, T., 2014. Reducing the bottom-hole differential pressure by vortex and hydraulic jet methods. Journal of Vibroengineering, 16(5), pp. 2224-2249.

10. Aldas, K. and Yapici, R., 2014. Investigation of effects of scale and surface roughness on efficiency of water jet pumping CFD. Engineering Applications of Computational Fluid Mechanics, 8(1), pp. 14-25.

\section{Дослідження кінематики потоків у камері змішування свердловинного струминного насоса}

\section{Є. І. Крижанівський, Д. О. Паневник}

Державний вищий навчальний заклад „Івано-Франківський національний технічний університет нафти і газу“, м. Івано-Франківськ, Україна, e-mail: rector@nung.edu. ua; den.panevnik@gmail.com

Мета. Удосконалення методу моделювання розподілу кінематичних параметрів змішуваних потоків у проточній частині свердловинного струминного насоса. 
Методика. Розроблена аналітична модель розподілу кінематичних параметрів потоку в камері змішування свердловинного струминного насоса у вигляді системи потенціальних течій і розміщеного між ними турбулентного шару 3 нерівномірним профілем швидкостей, апроксимованим із використанням елементарних функцій. У процесі моделювання використані інтегральні методи аналізу взаємодії асиметричних затоплених турбулентних струменів.

Результати. Використовуючи теорію затопленого струменя рідини, що рухається в супутній течії, проаналізована структура потоку на вході до камери змішування струминного насоса. Показана можливість моделювання процесу змішування коаксіальних потоків у вигляді автомодельних профілів швидкостей потенціальної та зсувної течій змінного перерізу із тришаровою структурою. Для областей потенціальних потоків прийнято рівномірний профіль швидкостей, а для розміщеної між ними зсувної течії - нелінійний профіль, що зберігають наближену автомодельність упродовж усієї початкової ділянки затопленого струменя. Інтегрування прийнятого профілю швидкостей, з урахуванням умов переходу між потенціальною та зсувною течіями, дозволило визначити нерівномірність розподілу кінематичних параметрів змішуваних потоків у проточній частині струминного насоса.

Наукова новизна. Полягає у встановленні взаємозв'язку між нерівномірністю автомодельних профілів швидкостей потенціальної та зсувної течій змінної структури, границями областей змішуваних потоків та взаємною орієнтацією елементів у проточній частині струминного насоса.

Практична значимість. Представлений метод оцінки нерівномірності профілю швидкостей у камері змішування струминного насоса дозволяє враховувати при моделюванні розподілу кінематичних параметрів змішуваних потоків конструкторські та експлуатаційні характеристики свердловинної ежекційної системи. Встановлений взаємозв'язок між нерівномірністю розподілу швидкостей і співвідношенням витрат змішуваних потоків, геометричних розмірів і взаємною орієнтацією елементів може використовуватись при проектуванні конструкцій і прогнозуванні режиму роботи свердловинного струминного насоса.

Ключові слова: нафтова свердловина, струминний насос, змішування потоків, профіль швидкостей

\section{Исследование кинематики потоков в камере смешивания скважинного струйного насоса}

\section{Е. И. Крыжанивский, Д. А. Паневник}

Государственное высшее учебное заведение „ИваноФранковский национальный технический университет нефти и газа“, г. Ивано-Франковск, Украина, e-mail: rector@nung.edu.ua; den.panevnik@gmail.com
Цель. Совершенствование метода моделирования распределения кинематических параметров смешиваемых потоков в проточной части скважинного струйного насоса.

Методика. Разработана аналитическая модель распределения кинематических параметров потока в камере смешивания скважинного струйного насоса в виде системы потенциальных течений и размещенного между ними турбулентного слоя с неравномерным профилем скоростей, аппроксимированным с помощью элементарных функций. При моделировании использованы интегральные методы анализа взаимодействия осесимметричных затопленных турбулентных струй.

Результаты. Используя теорию затопленной струи жидкости, движущейся в попутном течении, проанализирована структура потока на входе в камеру смешивания струйного насоса. Показана возможность моделирования процесса смешивания коаксиальных потоков в виде автомодельных профилей скоростей потенциального и сдвигового течений переменных сечений с трёхслойной структурой. Для областей потенциальных потоков принят равномерный профиль скоростей, а для размещённого между ними сдвигового течения - нелинейный профиль, которые сохраняют приближённую автомодельность вдоль всего начального участка затопленной струи. Интегрирование принятого профиля скоростей, с учетом условий перехода между потенциальным и сдвиговым течением, позволило определить неравномерность распределения кинематических параметров смешиваемых потоков в проточной части струйного насоса.

Научная новизна. Заключается в определении взаимосвязи между неравномерностью автомодельных профилей скоростей потенциального и сдвигового течений переменной структуры, границами областей смешиваемых потоков и взаимной ориентацией элементов в проточной части струйного насоса.

Практическая значимость. Представленный метод оценки неравномерности профиля скоростей в камере смешивания струйного насоса позволяет учитывать при моделировании распределения кинематических параметров смешиваемых потоков конструкторские и эксплуатационные характеристики скважинной эжекционной системы. Установленная зависимость между неравномерностью распределения скоростей и соотношением расходов смешиваемых потоков, геометрических размеров и взаимной ориентации элементов может использоваться при проектировании конструкций и прогнозировании режима работы скважинного струйного насоса.

Ключевые слова: нефтяная скважина, струйный насос, смешивание потоков, профиль скоростей

Рекомендовано до публікації докт. техн. наук I. I. Чудиком. Дата надходження рукопису 20.11.17. 